\title{
WORKS OF FOREIGN TOURISTS VISITING CENTRAL ASIA IN THE XIX CENTURY AS A SOURCE IN THE STUDY OF REGIONAL ETHNOTOPONYMS
}

\author{
Bekhzodjon Ilkhomjon Ugli Zokirov
}

Phd Doctoral Student, Researcher Tashkent State University Of Oriental Studies, Uzbekistan

\section{ABSTRACT}

This article classifies and analyzes the ethnotoponyms of the region, which are found in "travelogues" created based on travel memoirs of foreign tourists and officials of the countries who visited Central Asia in the XIX century. We know that ethnotoponyms are place names associated with "ethnos", which reflect the composition of the population of a particular area and the socio-economic processes associated with them, as well as traditions and values.

One of the most important issues of historical toponymy is the comparative analysis of ethnotoponyms based on known sources, the study of the ethnic composition of the population of the region, demographic processes and factors influencing them in terms of sourceology and historiography. In this regard, the study of place names in the khanates based on travelogues of foreign tourists visiting the Central Asian khanates, which are planned to be disclosed in the article, serves to fill in some gaps not mentioned in local sources.

The main purpose of the study is to recognize the source significance of travelogues in the study of Central Asian ethnotoponyms, and by determining the weight of ethnotoponyms in them, the general purpose of travelogues is to reveal their differences and similarities and to develop the principle of classification according to certain criteria.

The article used research methods such as systematic analysis, chronology, problem-chronological, as well as toponymic stratification of place names, genetic analysis, used in historical research.

As a result of the research, the role of travelogues as a common source and the total weight of ethnotoponyms of Central Asia in them were shown. The classification of existing ethnotoponyms, peculiarities of their emergence, theoretical and practical aspects of the study of ethnoponyms in the socioeconomic and ethnic history of the khanate was analyzed.

KEYWORDS: - Travelogue, ethnos, ethnonym, ethnotoponym, ethnooykonim, ethnohydronym, ethnooronym, Uzbek seeds.

\section{INTRODUCTION}

In the XIX century, the Central Asian khanates were visited not only by Russians, but also by European and some American tourists, whose memoirs and travelogues are a unique source for studying the place names of the khanate period, in particular, ethnotoponyms. The reason was that up to this time the share of foreign tourists visiting Central Asia was relatively small, and their travelogues did not contain enough information about this mysterious country. Therefore, during this period, many countries are determined to explore this part of Asia. As a result, by the end of the XIX century, many works and scientific literature about this region 
DOI: https://doi.org/10.37547/history-crjh-02-10-08

ISSN 2767-472X

(C)2021 Master Journals

\section{Crossref dof 81 Google}

Accepted 22thOctober, 2021 \& Published 27thOctober, 2021

appeared in Europe and America.

During the 19th century, ambassadors, traders, and missionaries traveled to Central Asia to explore the region. Below we review the travelogues of some European and American tourists included in our scope of research.

\section{Object ANd MEthods OF RESEARCH}

In this article, the memoirs, diaries, and published works of foreign tourists visiting Central Asia in the XIX century were selected as the object of research under the general name "travelogues" and the data on their ethnotoponyms were analyzed. The article also used special methods such as historicalchronological and comparative analysis and systematic approach used in historical research, as well as toponymic stratification used in toponymic research.

\section{DisCUSSION AND RESULTS}

We know that as a result of the struggle of Russia and Great Britain for spheres of influence in Central Asia, regular British visits to Central Asia began to be observed in the 1830s. One such tourist is Arthur Connolly, whose work "Journey to the North of India, overland from England, through Russia, Persia, and Affghaunistaun" is one of the most unique sources in the study of some aspects of the region's history. Arthur Connolly left London on August 10, 1829, and came to St. Petersburg through the Gulf of Finland, crossing the Baltic Sea, Hamburg, France, and northern Germany. Later, his travels continued through the Turkmen and Afghan territories, as well as Khiva, Bukhara, Kabul, Khorasan, Afghanistan to India[1]. The play names the largest cities in Central Asia, such as Goorgaun, Khiva, Karazm. Another important aspect of this travelogue for our research is that it contains valuable information about the aralian, kyrgyz, toorkmuns in the Khiva Khanate, as well as the Turkmen tribes such as goklan, yimoot, tekkah, attah and their regional location in the Khiva Khanate. In particular, the genealogical scheme of the Yavmut tree mentioned in the travelogue is of special scientific value in the interpretation of ethnotoponyms associated with this seed in Central Asia [2].

The travelogue of Alexander Burnes, one of the European tourists visiting Central Asia, is also distinguished by its richness of information. The Scottish diplomat and researcher joined the East India Army at the age of 16 and studied Urdu and Persian from Oriental languages during his years of service. Undoubtedly, his most important work is the three-volume "Travels into Bokhara", in which the author describes his impressions of a trip to Asia in 1829, 1832, and 1833 [3]. The play mentions the names of cities in Central Asia such as Khiva, Orgunje, Kurshee, Bokhara, Samarkand. Also, the author dwells on the ethnic composition of the population of the Emirate of Bukhara, adding that in addition to Uzbeks live in the emirate jews, hindus, persians, toorkmauns.

We can also learn from the general content of the travelogues that the tourists who came to Central Asia from the late 30 s of the XIX century came mainly for political purposes. However, in the works of authors who came in this period, along with many place names belonging to Central Asia, there are some ethnotoponyms and ethnonyms. In particular, the travelogue of Captain James Abbott, sent to Khiva in 1839, has a special significance in the study of the socioeconomic and political life of the khanate [4]. It is noteworthy that the travelogue contains some ethnotoponyms, such as Khaurism, Khiva, Huzzarrasp, Bokhara, Dahsh Hawz, Kohna Wuzeer, Ghoonguraut, Kara kalpak. The play also contains valuable information on the territorial location of ethnonyms in the khanate, such as 
DOI: https://doi.org/10.37547/history-crjh-02-10-08

ISSN 2767-472X

(C)2021 Master Journals

\section{Crossref dof 81 Google}

Accepted 22thOctober, 2021 \& Published 27thOctober, 2021

oozbeg, toorcumuns, koozulbaush, kuzzauk, chowdhoor, afghaun, kahr-a-kulpauk.

Joseph Wolf, a Jewish priest who visited Bukhara in 1843, and his travel story are also valuable sources on the history of Central Asia. In 1842, by order of Amir Nasrullah, he was appointed head of the British embassy mission to Bukhara to clarify the fate of British officers Ch. Stoddart and R. Canolly [5]. In particular, the author provides valuable information about the names of such cities as Khiva, Bukhara, Khokand, Samarkand, Shahr Sabz, Tashkent, Organsh, Oratepa, Korakol, Karki, Jessakh, as well as ethnonyms living in these cities: kasaks, kyrgyz, jews, nogais, uzbeks. In addition, the travelogue provides valuable information about the economy, training, ethnography of Bukhara Jews, which has a special place in the study of Bukhara Jews.

The travelogue with the most names of places among European tourists visiting Central Asia is undoubtedly the travelogue of A.Vambery, the author wrote several works on the history of the region as a result of his visit to the region [6]. Also, A. Vambery's "Geographical Names of Central Asia", a short introduction and more than 600 place names in the region, is recognized by toponymists in the study of existing place names in Central Asia in the XIX century, although some errors [7]. In the travelogue of A.Vambery he mentions the names of 32 cities of Khiva khanate [8]. It is also noteworthy that the largest macrotoponyms among them are Kungrat, Mangit, Khoha Ili, Chimbay, Kipchak, Khitay, Kiet, Djagatai, Yilali, Noks, Kiet-Kungrat, Kangli.

In his travelogue, A.Vambery lists the main villages not only in the capital Khiva, but also in other major cities. Some of such settlements in the khanate listed in the author's work are place names formed based on ethnonyms, including Kinik, Khasion, Toyasitchi, Tashayak, Sirtcheli,
Kiet in Khiva; Khojalar in Hozarasp, Eshontepa, Nogman, Karamaza in New Urgench, Kiptchak, Kiet, Nogai, Sarsar in Kungrad; Kongruds in Dashoguz, Bastirmali; Djelair, Alchin, Tashkali, Kargali in Gurlan; Naymans in the town of Khojayli, Kamishchali; Khojas in the city of Shahabad; Bogolon, Alielibay in the Kilichniyazbiy; Kiats in Mangit, Kenegoz; Nogai Eshan, Kondjirgali, Kanlilar in Kipchak.

Vambery's travels to the Central Asian khanates, in addition to the above-mentioned "Journey to Central Asia", he wrote "Essays on Central Asia" in 1867, which was published in London in 1868 [9]. The author notes the socio-historical topography of the khanate period, the ethnic composition of the population, ethnonyms associated with the Uzbek and Turkmen tribes, as well as many place names. In particular, Khiva, Tashhauz, Kungrat, Engi Urgench, Yilali, Gorlen, Khitayi, Kipchak, Porsu, Hezarasp, Khodja Ali, Khanka, Kerki, Tcharshuy, Shehr Sabz, Karschi, Bokhara, as well as Kermineh, Nur from the names of ancient places of Bukhara. Leaves valuable information on the etymology of historical toponyms such as Tavais, Ishkuhket, Zendine, Revane, Efshane, Berkend, Rametin, Varakh'sha, Beykend, Farob. Although ethnotoponyms are relatively less mentioned in this travelogue, the ethnonyms that form the basis for the formation of ethnotoponyms are quite common.

From the travelogues written by tourists visiting Central Asia in the 19th century, the richest factual material can be found in the works of American tourists. Although they visited the area later, the works belonging to other western tourists who had visited before them were consistently studied and supplemented. Also, since these authors visited Central Asia with the direct consent of the Russian government, the general appearance of their travelogues is characterized by a systematic study of the 
DOI: https://doi.org/10.37547/history-crjh-02-10-08

ISSN 2767-472X

(C)2021 Master Journals

\section{Crossref doi) 81 Google}

Accepted 22thOctober, 2021 \& Published 27thOctober, 2021

materials of Russian authors, not to overlook anything, and a clear definition of places and destinations. McGahan was one of the first American tourists to visit Central Asia and write a special work on the region. Born in the United States and a journalist by profession, McGahan's "Campaigning on the Oxus, and the Fall of Khiva" was published in London in 1874, detailing the Russian occupation of the Khiva Khanate in 1873 [10]. It was translated into Russian in 1875 and published on October 25, 1875 in Moscow State University Press under the title "Voennye deystviya na Oksuse i padenie Khivy" with the permission of the tsarist government [11]. Although the work consists of 3 chapters, mainly covering the processes related to the details of the battle, it mentions the names of many large and small cities and castles in the Khiva khanate. In particular, the play mentions ethnotoponyms such as Hazar-asp, Kungrad, Khojaili, Mangit, Iliali, Kara-kalpak, Sheik-Arik, as well as ethnonyms such as uzbeks, cossaks,turkmens, kyrgyz. In Chapter 3 of the work, the author gives information about the Turkmens of the Khiva khanate. For instance, alieli-goklens (alieligoklans-1500 grasses), yomuds (yovmuds-11000 grasses) with a total of 22,000 grasses and a total population of 110,000 Turkmen in the khanate [12]. These data are important in the study of place names associated with the Turkmen ethnonyms of the Khiva khanate, as well as the ethnic composition of the population.

Undoubtedly, Henry Lansdell's "Russian Central Asia" is another travelogue that reflects the names of historical and geographical places of Central Asia, as well as a wide range of information on the ethnography and ethnic history of the region [13]. Originally a church priest, Henry Lansdell made two major voyages during 1879-1882. In particular, one of them is to Siberia and the other to Central Asia, which creates the above work as a result of his second trip of exactly 179 days. As a result of his second voyage, Lansdell traveled a total of 12,145 miles $(19,545 \mathrm{~km})$ through Semipalatinsk, Kulja, Tashkent, Kokand, Samarkand, Karshi, Bukhara, Khiva, and Merv. While passing through these regions, the author mentioned many toponyms in his diaries, including Kungrad, Hojeili, Ilieli, Manghit, Kurama, Aravan, Durmoncha, Uyghur, Guz kishlak Goklenkal, Urus kishlak, Karamazy, Govozali, Kiatly, Hindu sarai, It mentions many ethnotoponyms such as Djiguiit-kala. The travelogue mentions ethno-names such as Kurama-Tau, Mogul-Tau, which are less common than other works, i.e., mountain names associated with ethnic names. Henry Lansdell also noted that the ethnic composition of the population in the Amudarya region is mainly karakalpaks, kazakhs, turkmens, uzbeks, persians and ural cossacks. Of these, Uzbeks and Tajiks make up the bulk of the sedentary population, while Kyrgyz are predominantly nomadic. In addition to large ethnonyms such as tajiks, persians, jews, hindus, arabs, uzbeks, kirghese, the Bukhara Emirate is home to uzbeks such as djagatai, kipchak, and ming. In general, this work of the author differs from foreign travelogues created in Central Asia in his time by the richness of information.

In addition, the travelogue written by another American tourist, Eugene Schuyler, as a result of his trip to Central Asia, has a special place in the study of place names and historical toponyms in the region. From 1870 to 1876 he served as secretary of the US diplomatic mission in St. Petersburg, during which time he traveled to Central Asia, sending detailed information about the results of the trip to the US National Geographic Society [14]. The work was published as a book in New York in 1876-1877. In the travelogue, E. Schuyler mentioned the names of many places in Syrdarya, Tashkent, Samarkand, Zarafshan valley, Khojand, Qurama, Kokand, 
DOI: https://doi.org/10.37547/history-crjh-02-10-08

ISSN 2767-472X

(C)2021 Master Journals

\section{Crossref dof 81 Google}

Accepted 22thOctober, 2021 \& Published 27thOctober, 2021

Bukhara. In the play, the author tried to explain the meaning of many historical toponyms in the region, in particular, the meaning of large cities such as Tashkent, Samarkand, Jizzakh, Shakhrisabz, Kitob, as well as many microtoponyms. Although ethnotoponyms do not constitute a quantitative majority among the place names mentioned by E.Schuyler in this travelogue, valuable information on many ethnonyms based on ethnotoponyms and their territorial location can be found. In particular, in the play we can find such ethnonyms as arabic, jalayir, kenagas, mangit, ming, nayman, olchin, uyghur, turkish, khitay, kipchak, kirq, kungirot.

\section{Conclusions}

In conclusion, the name of any place is closely connected with the traditions, customs, economic and socio-cultural life of the people living in the area. Alternatively, the origin of many place names may also be related to the names of different ethnic groups and clans living in the area, which we discussed above in the example of Central Asian ethnotoponyms. At the heart of these ethnotoponyms are political processes related to the socio-cultural life of certain ethnic groups, their prestige in the state and society, the study of which is important in opening some unknown pages of our history. As a result of the classification and analysis of ethno-toponyms of Central Asia in travelogues, the following conclusions were drawn.

-First of all, although the population of the Central Asian khanates is made up of different ethnic groups, the Uzbek tribes have their political influence, which we can see from the fact that the names of major cities are based on the names of these tribes.

-Second, the analysis of ethnotoponyms revealed that while the political influence of each ethnonym in the khanate depended on their location, while the influential population lived in strategically important areas, the political and economic opportunities of other ethnic units also depended on their place of residence.

-Thirdly, the ethno-toponyms of Central Asia in the travelogue are also directly related to the personality of the author who wrote this work.

-Fourth, the information in the travelogues is not always objective, and their comparative analysis with each other or with local sources is of particular practical importance in finding the right solution to the scientific problem posed in such source studies.

In general, the richness of information from the works of foreign tourists visiting Central Asia, based on more ethnographic observations, the simplicity of the language of writing, their source and historiographical analysis has a special practical significance in filling some unknown pages of regional history.

\section{ReFERENCES}

1. Arthur Conolly. Journey to the north of India overland from England through Russia, Persia and Affghaunistaun. Vol. 1. London, 1834. -P. 13

2. Arthur Conolly. Journey to the north of India overland from England through Russia, Persia and Affghaunistaun. Vol. 1. London, 1834. -P. 417.

3. Burnes Alexander. Travels into Bokhara. Vol 1. -London: John Murray, Albemarle street,1829. -P. 398; . Burnes Alexander. Travels into Bokhara. Vol 1. -London: John Murray, Albemarle street, 1834. -P. 508; Burnes Alexander. Travels into Bokhara. Vol 1. -London: John Murray, Albemarle street, 1834. -P. 374.; 
DOI: https://doi.org/10.37547/history-crjh-02-10-08

ISSN 2767-472X

(C)2021 Master Journals

\section{Crossref doi) 81 Google}

Accepted 22thOctober, 2021 \& Published 27thOctober, 2021

4. James Abbott. Narrative of a journey from Heraut to Khiva, Moscow, and St.Petersburgh, during the late Russian invasion of Khiva; some account of the court of Khiva and the kingdom Khaurism. Vol. 1. London, 1843. -P. 401.

5. Joseph Wolff. Narrative of a mission to Bokhara, in the years 1843-4845. New York, 1845. -P. 384.

6. Vambery Arminius. Travels in Central Asia. . -London: John Murray, Albemarle street, 1864. -P. 488; Vambery Arminius. Sketches of Central Asia. (Additioinal chapters of my travels, adventures and on the ethnology of Central Asia. -London: Wm. H.Allen\&CO., 13, Waterloo Place, Pall Mall, S.W., 1868. -P. 460.; Vambery A. Istoria Bokhara ili Transaksonii. -SPeterburg, 1873. -P. 569.

7. Khasanov Kh. The history of place names of Central Asia. -Tashkent: Fan, 1965. P.35.

8. Vambery Arminius. Travels in Central Asia. . -London: John Murray, Albemarle street, 1864. -P.353.

9. Vambery Arminius. Travels in Central Asia. . -London: John Murray, Albemarle street, 1864. -P. 488;

10. Mac Gahan J.A. Campaigning on the Oxus, and the fall of Kxiva. -New York: Happy \& Brothers, Franklin Square, 1874. -P. 438.

11. Военные действия на Оксусе и падение Хивы. Соч. Мак-Гахана. -М.: В Университетской типографии (Катков и $\left.\mathrm{K}^{\circ}\right), 1875$.

12. Mac Gahan J.A. Campaigning on the Oxus, and the fall of Kxiva. -New York: Happy \& Brothers, Franklin Square, 1874. -P. 349. (including Kuldja, Bokhara, Khiva and Merv). Vol. 1. -London. 1885. -P. 440.

14. Южин Скайлер. Туркистон: Россия Туркистони, Қўқон, Бухоро ва Гулжага саёхат қайдлари.//тарж. 3.Саидбобоев. Тошкент: O'zbekiston, 2019. -Б. 10.

15. https://www.wdl.org/ru/item/16720/ma nifest//Elizabeth Baigent, "Lansdell, Henry (1841-1919)," in Oxford Dictionary of National Biography (Oxford, U.K.: Oxford University Press, 2004).

16. Khasanov Kh. The history of place names of Central Asia. -Tashkent: Fan, 1965. -P. 80.

17. Yujin Skayler. Turkiston: Rossiya turkistoni, Qo'qon, Buxoro va Guljaga sayohat qaydlari.//tarj. Z.Saidboboyev. Toshkent: O'zbekiston, 2019. -B. 328.

18. Wambery H. Die Geographisiche Nomenklatur zentralasten, Petermanns, mittulungen. Band 37, 1891.;

19. Военные действия на Оксусе и падение Хивы. Соч. Мак-Гахана. -М.: В Университетской типографии (Катков и $\mathrm{K}^{\circ}$ ), 1875.

13. Henry Lansdell. Russian Central Asia 